\title{
Recykling kolejowych wagonów towarowych na przykładzie Polski
}

\begin{abstract}
$W$ artykule przedstawiono zagadnienia zwiqzane z recyklingiem towarowych wagonów kolejowych. Mimo braku regulacji prawnych zwiazanych $z$ zagospodarowaniem pojazdów szynowych recykling jest prowadzony z uwagi na korzyści ekonomiczne, które można czerpać z odzysku części i podzespołów wykorzystywanych jako części zamienne oraz z odzysku surowców wtórnych. W artykule opisano możliwości zagospodarowania wagonów towarowych wycofywanych z użytku na przyktadzie Polski. Przedstawiono skale zjawiska, istniejaca infrastrukture oraz proces demontażu i recyklingu na przyktadzie największego polskiego przewoźnika towarowego PKP Cargo.
\end{abstract}

\section{Wprowadzenie}

Rozwój gospodarczy, oprócz pozytywnych aspektów takich jak podnoszenie poziomu jakości życia społeczeństw, pociaga za sobą także negatywne skutki dla człowieka i środowiska naturalnego. Jednym $\mathrm{z}$ tych skutków są odpady generowane między innymi przez środki transportu zarówno na etapie produkcji, eksploatacji jak i wycofania z użytku. Sposobem na ograniczenie tego negatywnego wpływu jest odzysk, czyli gospodarcze wykorzystanie odpadów. Rosnąca świadomość ekologiczna we współczesnych społeczeństwach, wprowadzane regulacje prawne mające na celu ograniczanie ilości odpadów przeznaczonych do składowania, ale również korzyści ekonomiczne jakie można uzyskać z utylizacji zużytych produktów powodują, że tworzenie sieci recyklingu odpadów stało się ważnym problemem, szczególnie w krajach rozwiniętych.

W 2010 roku na całym świecie było eksploatowanych 2679,1 tys. wagonów towarowych, $\mathrm{z}$ tego 907,4 tys. w Europie. Ilość ta uległa zmniejszeniu od 2000 roku o 626,2 tys. sztuk w skali świata, w tym w Europie o 592,6 tys. wagonów [1]. Zmniejszenie ilości wagonów wynikało z faktu kasacji wagonów zużytych technicznie o znacznie mniejszych możliwościach przewozowych ładunków od wagonów towarowych wprowadzanych do eksploatacji w ostatnich kilkunastu latach, zwłaszcza w Europie i krajach wysoko rozwiniętych. Wycofywanie z użytku wagonów niezależnie od tego czy następuje w celu zastapienia ich bardziej efektywnymi jednostkami czy zmniejszenia taboru powoduje konieczność ich odpowiedniego zagospodarowania.

Środki transportu kolejowego są cennym źródłem materiałów, których recykling przynosi wymierne korzyści ekonomiczne. Wagony towarowe, podobnie jak inne środki transportu zbudowane są $\mathrm{z}$ różnych materiałów takich jak: stal, żeliwo, inne metale, drewno, kompozyty, malarskie powłoki ochronne, guma, elastomery, brezenty, smary. Odzysk tych materiałów z jednej strony przyczynia się do ograniczenia zapotrzebowania na surowce pierwotne, a $z$ drugiej strony zmniejsza zagrożenie dla środowiska naturalnego związane z niewłaściwym zagospodarowaniem głównie poprzez unikanie zanieczyszczenia ziemi i wód gruntowych substancjami niebezpiecznymi wykorzystanymi w ich budowie.

W tej sytuacji, wtórne wykorzystanie wycofywanych z eksploatacji wagonów towarowych jest wyzwaniem zarówno dla przewoźników podejmujących decyzje o ich wycofaniu, jak i producentów wagonów oraz administracji państwowej.

\section{Uregulowania prawne}

Kwestie recyklingu środków transportu zostały uregulowane wyłącznie w przypadku pojazdów samochodowych i to tylko samochodów osobowych i dostawczych o masie całkowitej do 3,5 tony. $\mathrm{Z}$ uwagi na to, że ilość odpadów powstających w wyniku wycofania z użytku taboru kolejowego jest znacznie mniejsza niż ilość odpadów z wycofanych z eksploatacji samochodów, zarówno władze międzynarodowe jak i krajowe, do chwili obecnej nie uregulowały kompleksowo problematyki recyklingu pojazdów szynowych.

Jedynym dokumentem odnoszącym się do recyklingu pojazdów szynowych jest Kodeks (Karta) Międzynarodowego Związku Kolei (UIC - International Union of Railways). Karta nr 345 E zatytułowana „Specyfikacje środowiskowe dla nowych pojazdów szynowych" [2] została wydana w czerwcu 2006 roku. Dokument ten odnosi się do aspektów ekoprojektowania i uwzględnienia na etapie projektowania oddziaływań środowiskowych generowanych przez pojazdy szynowe w trakcie całego cyklu życia. Karta UIC 345 E określa, że już na początku projektowania pojazdu 
szynowego producenci powinni stosować metodę REPID 2003, umożliwiającą uwzględnienie w procesie konstruowania takich aspektów jak: recykling materiałowy, efektywne zarządzanie zasobami, unikanie powstawania odpadów, uzyskiwanie jak najwyższego poziomu odzysku.

Mimo tego, że nie wprowadzono regulacji prawnych dotyczących odzysku wycofanych pojazdów szynowych, producenci i uczestnicy rynku przewozów kolejowych powinni wspierać europejską politykę w zakresie zagospodarowania odpadów. Jako punkty odniesienia powinny posłużyć standardy przemysłu samochodowego. Jednym z postulatów jest uwzględnianie w projektowaniu nowych pojazdów szynowych wymaganych poziomów odzysku i recyklingu określonych w Dyrektywie 2000/53/EC Parlamentu Europejskiego i Rady z dnia 18 września 2000 roku w sprawie pojazdów wycofanych $\mathrm{z}$ eksploatacji [3]. Zgodnie z wspomnianą dyrektywą wymagane poziomy odzysku powinny wynieść do 2015 roku $85 \%$, a od 2015 roku 95\% masy pojazdu. Ponadto do 2015 roku maksymalnie 5\% masy może zostać poddane odzyskowi energii (spalenie w celu wykorzystania energii zawartej w materiałach), a $80 \%$ masy powinno zostać poddane recyklingowi (recykling produktowy lub materiałowy). Od 2015 roku wskaźnik recyklingu zostanie podwyższony do $85 \%$, a maksymalnie $10 \%$ masy będzie mogło zostać spalone w celu odzysku energii.

W karcie 345 E postuluje się także wykorzystanie metody obliczeniowej zdolności pojazdów drogowych do recyklingu i odzysku, zawartej w normie ISO 22628, jako wzoru dla sektora kolejowego.

\section{Skala problemu w Polsce}

W Polsce w grudniu 2010 roku eksploatowano łącznie 89270 wagonów towarowych. Dla porównania w tym samym okresie eksploatowano 7885 wagonów do przewozu pasażerów [4]. W ciągu pięciu lat liczba wagonów towarowych zmniejszyła się o prawie $14 \%$, a wagonów osobowych o 11\%. Strukturę rodzajową wagonów towarowych eksploatowanych na koniec 2010 roku w Polsce przedstawiono w tabeli 1.

Struktura rodzajowa wagonów towarowych eksploatowanych w Polsce na koniec 2010 roku [4]

Tabela 1

\begin{tabular}{|l|c|}
\hline Wagony towarowe & $\mathbf{8 9 2 7 0}$ \\
\hline Wagony kryte & 5818 \\
\hline Wagony węglarki & 58572 \\
\hline Wagony platformy & 11976 \\
\hline Wagony cysterny & 7329 \\
\hline Wagony pozostałe & 5575 \\
\hline
\end{tabular}

W wyniku dokonanej w PKP w 1998 roku analizy posiadanych wagonów towarowych, uwzględniającej ilość według rodzajów, wiek wagonów, ich rozwiązania konstrukcyjne, techniczne zużycie oraz kształtujące się zmiany rodzajowe w kolejowym rynku przewozowym, opracowano program wycofania $\mathrm{z}$ użytku (kasacji) wagonów towarowych [6]. W programie tym założono wycofanie z użytku 27536 wagonów towarowych, ale w wyniku modyfikacji programu, liczba wagonów przeznaczonych do likwidacji uległa zwiększeniu. W latach 2003-2010 PKP Cargo wycofało z użytku 32609 wagonów (tab.3).

Największą liczbę wagonów wycofano z eksploatacji w 2010 roku, kiedy poddano recyklingowi 6305 wagonów. Począwszy od 2011 roku skala likwidacji wagonów ma być mniejsza i będzie wahać się od kilkuset do około 2 tysięcy wagonów rocznie. Na 2011 rok zaplanowano kasację 1805 wagonów towarowych. W przypadku pozostałych przewoźników kolejowych obecnych na polskim rynku przewozu ładunków nie występował dotychczas proces recyklingu wagonów. Dysponują oni stosunkowo młodym taborem, w części dzierżawionym lub leasingowanym. Problem recyklingu wagonów towarowych $\mathrm{w}$ tych przedsiębiorstwach w większej skali zacznie występować pod koniec obecnej dekady.

\section{Zagospodarowanie wycofanych wagonów to- warowych przez PKP Cargo}

Wobec braku międzynarodowych jak i krajowych uregulowań prawnych w zakresie recyklingu wagonów towarowych, największy polski przewoźnik kolejowy dokonuje kasacji wagonów w oparciu o własne, wewnętrzne uregulowania, stworzone na bazie wieloletnich doświadczeń, a także $\mathrm{w}$ oparciu o przepisy prawne z zakresu ochrony środowiska.

Pierwszym dokumentem regulującym sprawy likwidacji i recyklingu wagonów towarowych $\mathrm{w}$ spółce PKP Cargo było Zarządzanie nr 36 Zarządu PKP Cargo S.A. z 9 października 2002 roku w sprawie zasad i trybu wycofywania wagonów towarowych z eksploatacji ze względu na ich stan techniczny, likwidacji wagonów jako środków trwałych i kasacji wagonów wycofanych $\mathrm{z}$ eksploatacji [7]. W wyniku zdobytego w ciagu kilku lat obowiązywania powyższego zarząadzania doświadczenia i wiedzy, opracowano nowy dokument pt. Zasady likwidacji wagonów", który został wdrożony uchwała nr 422/2009 Zarządu PKP Cargo S.A. z 20 sierpnia 2009 roku [8]. Zasady te wyznaczają tok postępowania od momentu zgłoszenia wagonu do wycofania z eksploatacji aż do zakończenia procesu jego fizycznej likwidacji. Likwidacja wagonów obejmuje całokształt czynności $\mathrm{z}$ punktu widzenia przewoźnika, czyli właściciela wagonu, związanych $\mathrm{z}$ wycofaniem wagonu $\mathrm{z}$ eksploatacji. Zasady definiują także czynności powiązane $\mathrm{z}$ likwidacją wagonów jak np. kasacja wagonu, czyli 


\begin{tabular}{|c|c|c|c|c|c|c|c|c|c|c|}
\hline \multirow[b]{2}{*}{ Rodzaj wagonu } & \multirow[b]{2}{*}{ Liczba } & \multirow[b]{2}{*}{$\begin{array}{c}\text { Udzial } \\
\%\end{array}$} & \multicolumn{8}{|c|}{ Średni wiek wagonu w latach } \\
\hline & & & $\begin{array}{c}\text { do } 5 \\
\text { lat }\end{array}$ & $\begin{array}{c}6-10 \\
\text { lat }\end{array}$ & $\begin{array}{c}11- \\
15 \text { lat }\end{array}$ & $\begin{array}{c}16- \\
20 \text { lat }\end{array}$ & $\begin{array}{c}21- \\
25 \text { lat }\end{array}$ & $\begin{array}{c}26- \\
30 \text { lat }\end{array}$ & $\stackrel{>}{30 \text { lat }}$ & $\begin{array}{c}\text { Średni } \\
\text { wiek } \\
\text { wagonu }\end{array}$ \\
\hline Węglarki budowy normalnej & 38061 & 54,97 & 1651 & 62 & 1852 & 1 & 22699 & 6976 & 4820 & 24,3 \\
\hline Węglarki budowy specjalnej & 11150 & 16,10 & 959 & 2093 & 749 & 0 & 590 & 713 & 6046 & 24,5 \\
\hline Kryte budowy normalnej & 3806 & 5,50 & 0 & 0 & 0 & 176 & 1452 & 840 & 1338 & 28,7 \\
\hline Kryte budowy specjalnej & 2092 & 3,02 & 1 & 214 & 751 & 103 & 455 & 68 & 500 & 21,3 \\
\hline Platformy budowy normalnej & 6066 & 8,76 & 0 & 0 & 102 & 348 & 2007 & 1506 & 2103 & 27,6 \\
\hline Platformy budowy specjalnej & 5102 & 7,37 & 145 & 76 & 373 & 28 & 2275 & 551 & 1654 & 25,8 \\
\hline$Z$ otwieranym dachem & 747 & 1,08 & 0 & 0 & 60 & 0 & 404 & 201 & 82 & 24,6 \\
\hline Specjalne & 1701 & 2,46 & 0 & 0 & 0 & 0 & 0 & 1651 & 50 & 29,2 \\
\hline Cysterny & 34 & 0,05 & 0 & 0 & 0 & 0 & 0 & 0 & 34 & 41,0 \\
\hline Służbowe & 486 & 0,70 & 0 & 0 & 0 & 0 & 202 & 9 & 275 & 38,1 \\
\hline Razem & 69245 & 100,0 & 2756 & 2445 & 3887 & 656 & 30084 & 12515 & 16902 & 25,1 \\
\hline Udzial [\%] & 100,0 & & 3,98 & 3,53 & 5,61 & 0,95 & 43,45 & 18,07 & 24,41 & \\
\hline
\end{tabular}

Struktura wagonów towarowych wycofanych z użytku przez PKP Cargo w latach 2003-2010 [5]

Tabela 3

\begin{tabular}{|l|r|r|r|r|r|r|r|r|r|}
\hline Typ wagonu & $\mathbf{2 0 0 3}$ & $\mathbf{2 0 0 4}$ & $\mathbf{2 0 0 5}$ & $\mathbf{2 0 0 6}$ & $\mathbf{2 0 0 7}$ & $\mathbf{2 0 0 8}$ & $\mathbf{2 0 0 9}$ & $\mathbf{2 0 1 0}$ & Ogólem \\
\hline $\begin{array}{l}\text { Wagony kryte budowy } \\
\text { normalnej }\end{array}$ & 416 & 782 & 709 & 798 & 342 & 894 & 1315 & 1628 & $\mathbf{6 8 8 4}$ \\
\hline $\begin{array}{l}\text { Wagony platformy bu- } \\
\text { dowy normalnej }\end{array}$ & 76 & 157 & 207 & 146 & 103 & 305 & 309 & 934 & $\mathbf{2 2 3 7}$ \\
\hline $\begin{array}{l}\text { Wagony weglarki budo- } \\
\text { wy specjalnej }\end{array}$ & 23 & 42 & 34 & 135 & 492 & 318 & 434 & 781 & $\mathbf{2 2 5 9}$ \\
\hline $\begin{array}{l}\text { Wagony z dachem od- } \\
\text { chylnym }\end{array}$ & & & & & & 1 & & & $\mathbf{1}$ \\
\hline Wagony chłodnie & 50 & 86 & 78 & 13 & 4 & & & & $\mathbf{2 3 1}$ \\
\hline $\begin{array}{l}\text { Wagony weglarki budo- } \\
\text { wy normalnej }\end{array}$ & 2506 & 3457 & 2321 & 2217 & 832 & 2207 & 1775 & 2785 & $\mathbf{1 8 1 0 0}$ \\
\hline Wagony cysterny & 1695 & 187 & 205 & 181 & 19 & 69 & 66 & 152 & $\mathbf{2 5 7 4}$ \\
\hline Wagony specjalne & 50 & 5 & 23 & 10 & 2 & 162 & 5 & 23 & $\mathbf{2 8 0}$ \\
\hline $\begin{array}{l}\text { Wagony platformy bu- } \\
\text { dowy specjalnej }\end{array}$ & 27 & 5 & & & 1 & 1 & 1 & & $\mathbf{3 5}$ \\
\hline $\begin{array}{l}\text { Wagony kryte budowy } \\
\text { specjalnej }\end{array}$ & $\mathbf{4 8 4 3}$ & $\mathbf{4 7 2 5}$ & $\mathbf{3 5 7 7}$ & $\mathbf{3 5 0 0}$ & $\mathbf{1 7 9 5}$ & $\mathbf{3 9 5 8}$ & $\mathbf{3 9 0 6}$ & $\mathbf{6 3 0 5}$ & $\mathbf{3 2 6 0 9}$ \\
\hline Razem & & & & & & & & \\
\hline
\end{tabular}


całokształt działań formalnych, technicznych i organizacyjnych, mających na celu fizyczną likwidację wagonu towarowego.

W zakres kasacji wagonu wchodzą:

- rozbiórka oraz cięcie wagonu z pozyskaniem: sprawnych części, zespołów, podzespołów, elementów i materiałów oraz złomu,

- rozliczenie odzyskanych części, materiałów oraz złomu, rozliczenie odpadów i ubytków, przygotowanie wymaganych dokumentów.

Kasacja obejmuje zatem demontaż wagonów, segregację części oraz odpadów do ponownego wykorzystania, a także odpadów do składowania i przekazanie ich odpowiednim jednostkom.

Proces likwidacji wagonów towarowych określony w Zasadach likwidacji wagonów obejmuje następujące fazy:

1. Tryb zgłoszenia wagonów do wycofywania $z$ eksploatacji ze względu ma stan techniczny.

2. Komisyjne oględziny wagonu zgłoszonego do wycofywania ze względu na stan techniczny.

3. Decyzja o wycofaniu wagonu $z$ eksploatacji.

4. Przekazanie wagonów do fizycznej likwidacji.

5. Kasacja wagonów.

6. Rozliczenie kasacji wagonów.

Po ocenie wagonów komisja kasacyjna ostatecznie ustala listę podzespołów i części nadających się do dalszego wykorzystania w eksploatacji, które należy odzyskać z kasowanego wagonu. Lista ta w szczególności obejmuje: wózki, zestawy kołowe, urządzenia cięgłowe, zderzaki, resory, zawór rozrządczy. Części te podlegają tzw. recyklingowi produktowemu, czyli są traktowane jako części zamienne do wykorzystania w trakcie obsługi serwisowej wagonów będących w eksploatacji bezpośrednio lub po przeprowadzeniu procesu regeneracji.

Wagony są następnie przekazywane do demontażu. Demontaż może być przeprowadzany albo w zakładzie należącym do spółki PKP Cargo zajmującym się kasacją wagonów albo w uprawnionym do tego podmiocie zewnętrznym na podstawie umowy lub jeżeli transport wagonów nie jest możliwy w miejscu ich postoju. W miejscu postoju wagonu demontaż przeprowadzany jest albo przez pracowników spółki lub przez pracowników innych przedsiębiorstw na podstawie zawartej umowy.

Spółka PKP Cargo posiada wymagane pozwolenia na wytwarzanie odpadów i gospodarowanie nimi oraz zbiórkę i składowanie surowców wtórnych, powstających w wyniku kasacji wagonów, ich przeglądów i napraw oraz wymiany w nich podzespołów [5].

Niezależnie od miejsca wykonywania demontażu kasacja wagonów powinna być przeprowadzona $\mathrm{z}$ należytą starannością, w szczególności, jeżeli chodzi o odzyskiwanie zespołów i podzespołów, segregację złomu, drewna i odpadów oraz minimalizację ubytków, z zachowaniem obowiązujących przepisów
BHP, przeciwpożarowych i ochrony środowiska. Kasacja powinna być prowadzona $\mathrm{w}$ taki sposób, aby nie była możliwa odbudowa wagonu, a żaden zespół lub podzespół zakwalifikowany na złom, nie mógł zostać ponownie wykorzystany $\mathrm{w}$ innym wagonie. Cel ten uzyskuje się poprzez przecięcie palnikiem głównych części konstrukcji.

Podczas kasacji każdego wagonu istnieje obowiązek pocięcia wagonu na złom klasy W1, N5 (zestawy kołowe), N10 oraz ZZ8 w taki sposób, aby uzyskać jak największą ilość złomu klasy W1. Złom odzyskany $\mathrm{z}$ kasowanego wagonu należy posegregować na klasy i przechowywać $\mathrm{w}$ postaci posegregowanej do momentu jego odbioru. Odzyskane z kasowanych wagonów części zamienne i podzespoły przewidziane do dalszego obrotu materiałowego oraz złom w ustalonych klasach, cenach i wadze przekazywane są do magazynu.

Ważnym zapisem ujętym w Zasadach likwidacji wagonów jest zapis, zgodnie z którym podczas rozliczenia kasowanego wagonu w ogólnym bilansie dopuszcza się maksymalnie do 5\% ubytków łącznej masy w stosunku do łącznej masy wagonu ustalonej przed jego kasacją w wyniku ważenia bądź szacowania.

\section{Miejsca przeprowadzania recyklingu wagonów w Polsce}

W Polsce funkcjonuje około 10 niezależnych przedsiębiorstw zajmujących się demontażem oraz recyklingiem materiałowym wagonów kolejowych oraz 11 zakładów należących do grupy PKP Cargo (rys.1).

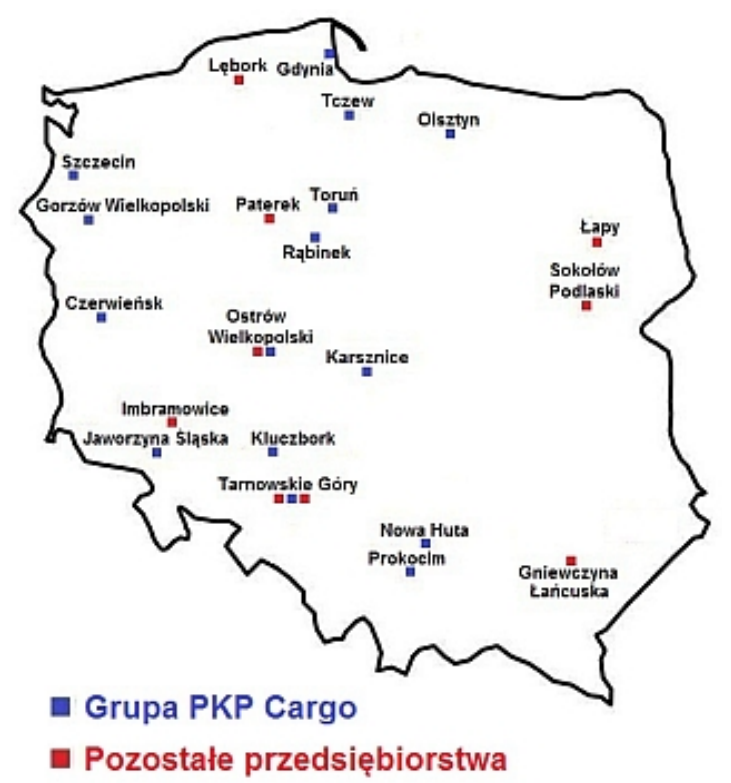

Rys.1. Lokalizacja przedsiębiorstw zajmujących się recyklingiem wagonów wycofanych z użytku 
Główny obszar działalności przedsiębiorstw nie należących do PKP Cargo obejmuje inną działalność niż zagospodarowanie pojazdów szynowych. Zajmują się one przede wszystkim naprawą i modernizacją taboru kolejowego, zagospodarowaniem złomu i surowców wtórnych (w tym samochodów wycofanych z eksploatacji), a nawet produkcją wagonów. Są to przedsiębiorstwa takie jak:

- Wagon Ostrów S.A. w Ostrowie Wielopolskim,

- Zakłady Naprawcze Taboru Kolejowego „Łapy" S.A. w Łapach,

- Zakłady Naprawcze Taboru Kolejowego „Paterek" S.A. w Paterku k/Nakła nad Notecią,

- Fabryka Wagonów „Gniewczyna” S.A. w Gniewczynie Łańcuckiej,

- Przedsiębiorstwo Przerobu Złomu Metali „Segromet" Sp. z o.o. w Sokołowie Podlaskim,

- Złomowanie, Recykling, Autozłom, Surowce Wtórne Olmet Sp. z o.o. w Tarnowskich Górach,

- Punkt Skupu Surowców Wtórnych Kazimierz Bandzmer w Lęborku,

- „Złomstal FHU Podczasy S.” w Imbramowicach,

- Inverta - Bocar Sp. z o.o. w Tarnowskich Górach.

Z kolei w Grupie PKP Cargo recyklingu wagonów towarowych dokonuje się w 11 wydzielonych organizacyjnie podmiotach zajmujących się przede wszystkim naprawą i serwisowaniem taboru, ale świadczących także usługi złomowania i recyklingu wagonów w 15 miejscowościach zlokalizowanych na obszarze całego kraju [5]. Są to:

- PKP Cargo Wagon - Jaworzyna Śląska Sp. z o.o.,

- PKP Cargo Wagon - Kraków Sp. z o.o. (wykonująca usługi w zakresie wagonów towarowych w Krakowie - Prokocimiu i Krakowie - Nowej Hucie),

- PKP Cargo Wagon - Szczecin Sp. z o.o.,

- PKP Cargo Wagon - Tarnowskie Góry Sp. z o. o.,

- PKP Cargo Wagon - Toruń Sp. z o.o. (wykonująca usługi w zakresie wagonów towarowych $w$ Toruniu i Inowrocławiu - Rąbinku),

- PKP Cargo Tabor - Czerwieńsk Sp. z o.o.,

- PKP Cargo Tabor - Karsznice Sp. z o.o.,

- PKP Cargo Tabor - Ostrów Wielkopolski Sp. z o.o.,

\section{Zakres recyklingu}

W przypadku wagonów kolejowych możliwe są dwie metody recyklingu: ręczna i zmechanizowana. Należy jednak pamiętać, że wykorzystując metodę zmechanizowaną nie ma możliwości zastosowania pełnej me- chanizacji tak jak przy demontażu taśmowym stosowanym w stacjach demontażu samochodów wycofanych z eksploatacji. Ręczny demontaż jest konieczny zawsze w celu pozyskiwania zespołów, elementów i części nadających się do dalszego użytku lub regeneracji (recykling produktowy). Demontaż mechaniczny ma na celu przyspieszenie operacji związanych z cięciem i transportem elementów i służy do odzyskiwania surowców wtórnych (recykling materiałowy).

Proces recyklingu produktowego rozpoczyna się od zdemontowania wózków, zderzaków i elementów cięgłowych oraz elementów aparatury hamulcowej.

Po demontażu podzespołów dokonuje się wzrokowej oceny elementów pod względem braku pęknięć, pokrzywien, przerdzewiałych miejsc i przydatności do bezpośredniego ponownego wykorzystania lub regeneracji.

W przypadku stwierdzenia uszkodzenia ramy wózka (pęknięcia, przerdzewiałe miejsca, pokrzywienia), przy jednoczesnym potwierdzeniu przydatności omaźnicowanych zestawów kołowych lub samych osi posiadających znaki cechowania określających ich rok produkcji, dokonuje się demontażu wózka, przeznaczając ramę na złom, a zestawy kołowe z maźnicami lub osie do dalszego użytkowania. Analogicznie postępuje się, gdy uszkodzone są zestawy kołowe lub osie, a rama jest nieuszkodzona. W przypadku demontażu wózka wymontowuje się trójkąty hamulcowe stwierdzając ich przydatność do dalszego użytku lub przeznaczając na złom. Zdemontowane zderzaki z wkładami elastomerowymi, w przypadku stwierdzenia braku mechanicznych uszkodzeń lub pęknięć elementów metalowych przeznacza się do regeneracji.

Części i podzespoły wykorzystywane $\mathrm{w}$ recyklingu produktowym to najczęściej: wózki, ramy wózków, zestawy kołowe, ostoje wagonu, urządzenia cięgłowe, zderzaki, resory, trójkąty hamulcowe, kurki końcowe, systemy hamulcowe, zawory rozrządcze hamulca, zawory ważące. Pozyskanie powyższych zespołów i części do napraw, modernizacji i produkcji nowych wagonów towarowych ma istotny wpływ na opłacalność procesu recyklingu. Odzyskane produkty z wycofywanych $\mathrm{z}$ użytku wagonów stanowią średnio w zależności od rodzaju wagonu od $18,9 \%$ do $28,4 \%$ przeciętnej masy wagonów [9].

Po wyselekcjonowaniu i wymontowaniu części i podzespołów nadających się do dalszego użytkowania, kolejnym etapem jest odzysk materiałów. Najpierw w celu uniemożliwienia ponownego, nielegalnego wprowadzenia do ponownego obiegu elementów przeznaczonych do likwidacji, dokonuje się przynajmniej jednokrotnego przecięcia ostoi wagonu i ramy wózków, a kasowane zestawy kołowe zostaja uszkodzone przez ukośne nacięcie czopa osi na szerokości i głębokości nie mniejszej niż $40 \mathrm{~mm}$ oraz jednomiejscowe nacięcie obrzeży kół na głębokości nie mniejszej niż 40 pod kątem $90^{\circ}$ [9]. Następnie przy- 
stępuje się do pocięcia wszystkich pozostałych elementów w tym pudła wagonu. Operacja ta może być przeprowadzona ręcznie przy pomocy palników lub mechanicznie z wykorzystaniem wielofunkcyjnych, głównie mobilnych, maszyn i urządzeń. Do mechanicznego demontażu można wykorzystywać między innymi wielofunkcyjną maszynę wyposażoną w nożyce do cięcia złomu, chwytak, płytę magnetyczną oraz hak ładunkowy. Do transportu wewnętrznego złomu można stosować samojezdną ładowarkę hydrauliczną, urządzenie często wykorzystywane $\mathrm{w}$ przedsiębiorstwach zajmujących się skupem i obrotem złomu.

W wyniku recyklingu materiałowego wagonów towarowych, największą odzyskiwaną masę stanowi złom stalowy zaliczany zgodnie z polską normą $\mathrm{PN}-85 / \mathrm{H}$ - 15000 do następujących klas:

- W1 - złom stalowy kawałkowy wsadowy niestopowy o największych wymiarach 1000 x 500 x $500 \mathrm{~mm}$ o grubości $6 \mathrm{~mm}$ i powyżej oraz maksymalnej masie $2000 \mathrm{~kg}$; koła i obręcze kolejowe o średnicy do $1100 \mathrm{~mm}$,

- N10 - złom stalowy pomieszany niewsadowy niestopowy.

Niezależnie od powyższych dominujących klas złomu uzyskuje się także niewielkie ilości złomu wysokiej klasy oznaczonego symbolem W1R oraz złomu żeliwnego oznaczonego symbolem ZZ8. Udział uzyskiwanego złomu klasy W1R zależnie od rodzaju wagonu stanowi od $0,2 \%$ do $4,6 \%$ całkowitej masy wagonu, a udział złomu żeliwnego stanowi od $0,1 \%$ do $0,4 \%$ ogólnej masy wagonu (tab.4). Ponadto w wyniku złomowania niektórych elementów wyposażenia wagonu towarowego m.in. kurka końcowego uzyskuje się nieznaczne ilości złomu metali kolorowych jak np. mosiądzu czy aluminium. Ilości te maksymalnie mogą wynosić kilka kilogramów.

$\mathrm{W}$ procesie utylizacji wagonów towarowych odzyskuje się także materiały, które nie są wykorzystywane w recyklingu materiałowym, ale są wykorzystywane jako źródło energii (tzw. odzysk energii). Do tych materiałów należą głównie drewno oraz w niewielkich ilościach smary i elementy gumowe, elastomerowe oraz brezenty. Udział drewna w masie wagonu w zależności od rodzaju wagonu wynosi od $2,7 \%$ do $11,4 \%$ masy wagonu.

$\mathrm{W}$ procesie zagospodarowania wagonów towarowych oprócz odzysku produktów i materiałów nadających się do ponownego użycia, powstają odpady, które podlegają wyłącznie składowaniu. Odpady te to między innymi skorodowane powłoki malarskie, zabrudzenia i zanieczyszczenia pochodzące $\mathrm{z}$ przewożonych towarów i ładunków.

\section{Podsumowanie}

Mimo, że nie istnieją w obszarze pojazdów szynowych regulacje prawne odnoszące się do recyklingu wycofanego z eksploatacji taboru, odpowiednie zagospodarowanie tego typu odpadów jest koniecznością wynikająca $\mathrm{z}$ ogólnych zasad gospodarowania odpadami. Do tej pory główną motywacją do przeprowadzania recyklingu były korzyści ekonomiczne jakie można czerpać z odzysku metali lub sprzedaży podzespołów nadających się do dalszego wykorzystania. Należy liczyć się jednak z tym, że zwłaszcza w krajach rozwiniętych, gdzie wdrażana jest polityka zrównoważonego rozwoju, problematyka recyklingu pojazdów szynowych stanie się przedmiotem zainteresowania, a docelowo ścisłych regulacji prawnych.

Udzial procentowy złomu w ogólnej masie wagonów towarowych wycofanych z użytku przez PKP Cargo w 2011 r. [5]

Tabela 4

\begin{tabular}{|l|c|c|c|c|c|}
\hline Rodzaj wagonu & $\begin{array}{c}\text { Przeciętna } \\
\text { masa } \\
\text { wagonu w kg }\end{array}$ & $\begin{array}{c}\text { Zlom } \\
\text { stalowy } \\
\mathbf{W 1}\end{array}$ & $\begin{array}{c}\text { Zlom } \\
\text { stalowy } \\
\text { N10 }\end{array}$ & $\begin{array}{c}\text { Zlom } \\
\text { stalowy } \\
\text { W1R }\end{array}$ & $\begin{array}{c}\text { Zlom } \\
\text { zeliwny } \\
\text { ZZ8 }\end{array}$ \\
\hline $\begin{array}{l}\text { Węglarka budowy normalnej } \\
\text { z podłoga metalową - 4-osiowa }\end{array}$ & 18554 & $60,2 \%$ & $8,9 \%$ & $1,2 \%$ & $0,3 \%$ \\
\hline $\begin{array}{l}\text { Węglarka budowy normalnej } \\
\text { z podłogą drewnianą-4 osiowa }\end{array}$ & 18518 & $56,5 \%$ & $8,1 \%$ & $0,2 \%$ & $0,4 \%$ \\
\hline $\begin{array}{l}\text { Wagon kryty budowy normalnej 4 } \\
\text { osiowy }\end{array}$ & 21139 & $47,9 \%$ & $9,8 \%$ & $0,4 \%$ & $0,3 \%$ \\
\hline $\begin{array}{l}\text { Wagon kryty budowy normalnej 2 } \\
\text { osiowy }\end{array}$ & 14128 & $55,2 \%$ & $11,5 \%$ & $0,5 \%$ & $0,2 \%$ \\
\hline $\begin{array}{l}\text { Wagon platforma budowy } \\
\text { normalnej 4 osiowa }\end{array}$ & 11705 & $66,6 \%$ & $1,5 \%$ & $0,4 \%$ & $0,1 \%$ \\
\hline $\begin{array}{l}\text { Wagon węglarka budowy } \\
\text { specjalnej 2 osiowa }\end{array}$ & 10327 & $60,6 \%$ & $9,3 \%$ & $4,6 \%$ & $0,2 \%$ \\
\hline $\begin{array}{l}\text { Wagon platforma budowy } \\
\text { normalnej 2 osiowa }\end{array}$ & 28000 & $68,9 \%$ & $9,0 \%$ & $1,2 \%$ & $0,3 \%$ \\
\hline $\begin{array}{l}\text { Wagon węglarka budowy } \\
\text { specjalnej 4 osiowa }\end{array}$ & $66,0 \%$ & $1,2 \%$ & $0,0 \%$ & $0,1 \%$ \\
\hline
\end{tabular}


Odpowiednie zagospodarowanie wycofanych pojazdów szynowych, w tym wykorzystanie produktów i surowców pozyskanych w drodze recyklingu przyczynia się bowiem do:

- zmniejszenia zanieczyszczenia środowiska naturalnego,

- zmniejszenia zużycia surowców pierwotnych,

- obniżenia kosztów produkcji i napraw wyrobów,

- zmniejszenia kapitałochłonności i energochłonności produkcji.

Osiagnięcie wysokich poziomów recyklingu i odzysku wymaganych dla pojazdów samochodowych nie stanowi problemu w przypadku zagospodarowania wagonów towarowych, natomiast będzie stanowić problem w przypadku pojazdów trakcyjnych oraz wagonów przeznaczonych do przewozu osób.

Zagwarantowanie odpowiedniego poziomu odzysku możliwe będzie wyłącznie wtedy, kiedy wymagania związane $z$ demontażem i recyklingiem będą uwzględniane na etapie konstruowania pojazdów szynowych. Trzeba wprowadzić system nowoczesnych modułowych technologii zapewniających łatwą budowę pojazdów i jednocześnie ułatwiony demontaż (zapewnienie łatwego i prostego rozdziału materiałów przy kasacji pojazdu). Poza tym istotny jest także dobór materiałów i udostępnienie przez producentów odpowiedniej dokumentacji pojazdów.

W Polsce istnieje odpowiednia baza techniczna umożliwiająca fizyczną utylizację pojazdów szynowych. Należy jednak liczyć się z inwestycjami w wyposażenie techniczne niezbędne do przeprowadzenia procesu recyklingu produktowego i materiałowego pojazdów szynowych zwłaszcza zespołów trakcyjnych.

\section{Literatura:}

[1] International Union of Railways, Railway Statistics Synopsis 2000- 2009, www.uic.org

[2] Kodeks UIC 345 E pt. Specyfikacje środowiskowe dla nowych pojazdów szynowych, International Union of Railways, Wydanie 1, 1.06.2006.

[3] Dyrektywa 2000/53/EC Parlamentu Europejskiego $i$ Rady z 18 września 2000 w sprawie pojazdów wycofanych $z$ eksploatacji, Dziennik oficjalny OJ269, 21.10.2000.

[4] Transport Wyniki Działalności w 2010 roku, Gtówny Urzad Statystyczny, Warszawa 2011.

[5] Materiaty informacyjne PKP Cargo S.A.

[6] Polityka inwestycyjna PKP w zakresie taboru trakcyjnego i wagonowego na lata 1999-2010, Kraków 1998.

[7] Zarzqdzenie nr 36 Zarzqdu PKP Cargo S.A. z 9 października 2002 roku $w$ sprawie zasad $i$ trybu wycofywania wagonów towarowych z eksploatacji ze względu na ich stan techniczny, likwidacji wagonów jako środków trwatych $i$ kasacji wagonów wycofanych $z$ eksploatacji. Dokumenty wewnętrzne PKP Cargo S.A.

[8] Zasady likwidacji wagonów. Regulamin PKP Cargo S.A. z 20 sierpnia 2009. Dokumenty wewnętrzne PKP Cargo S.A.

[9] Materiaty przedsiębiorstw przeprowadzajacych demontaż wagonów towarowych m.in. Wagon Ostrów w Ostrowie Wlkp., Tabor Szynowy w Opolu, spótki grupy PKP Cargo, Olmet w Tarnowskich Górach, Złomstal FHU Podczasy S. w Imbramowicach, Segromet $w$ Sokołowie Podlaskim. 